7. med. Genet. (1969). 6, 5.

\title{
A Prospective, Cytogenetic Study of Recurrent Abortion
}

\author{
J. A. WILSON
}

\author{
From the Nuffield Unit of Medical Genetics, Department of Medicine, University of Liverpool
}

Many workers have now recorded a high incidence of chromosomal abnormalities in spontaneously aborted foetuses, particularly in those aborted in the first trimester of pregnancy and in those which are macroscopically abnormal. Kerr and Rashad (1966) found an incidence of $21 \%$ of chromosomal abnormalities in 400 specimens recorded in the world literature. A higher incidence of abnormalities may be found in series confined to first trimester abortions, ranging from 33\% (Kerr and Rashad, 1966) to over $60 \%$ (Szulman, 1965; Thiede and Salm, 1964). The common abnormalities of karyotype are 45,X, various trisomies, and triploidy or tetraploidy. Occasional autosomal monosomies have been reported in early specimens (Inhorn, Therman, and Patau, 1964; Kelly et al., 1965; Jacobson and Barter, 1967; Waxman, Arakaki, and Smith, 1967).

Most of these workers studied random cases of spontaneous abortion, and few cytogenetic studies of recurrent abortions have been carried out. The possibility of transmissible chromosomal anomalies causing habitual abortion has been suggested on the basis of findings in individual families by Schmid (1962), Carr (1963), and Jacobsen, Dupont, and Mikkelsen (1963) who found possible translocations, by Bishun et al. (1964) who described a case of maternal chromosome mosaicism, and by Jacobson and Barter (1967) who described a case of a woman having a probable isochromosome 18 (long arms).

Rowley, Marshall, and Ellis (1963) made a retrospective study of 22 women with a history of three or more spontaneous abortions, but they examined the husband's karyotype in only 7 cases. The only abnormality found was a long $\mathrm{Y}$ chromosome in one of the men. Wingate (1965), however, examined 22 couples with a history of three or more abortions and found a possible translocation between the short arms of chromosome 17 or 18 and the short arms of a G autosome in 5 of the women.

Received April 19, 1968.
Carr (1967), pointing out that abnormalities of the type described by Schmid (1962), Wingate (1965), and himself (1963) are now usually considered to be variants of the normal, concluded it was unlikely that chromosomal anomalies were a common cause of habitual abortion. The conflict of results is probably, in part, a consequence of the small numbers yet studied.

It was considered that the incidence of chromosomal anomalies in couples subject to habitual abortion would be determined only by a prospective, and, if possible, consecutive study of both partners, with foetal studies whenever material became available. The results of a study of 50 families as they presented to one hospital is here reported.

\section{Patients and Methods}

Walton Hospital has a ward of 31 beds which admits all cases of abortion, threatened abortion, and complications of abortion accepted by the hospital. It also admits pregnant women with a previous history of abortions for prophylactic rest in early pregnancy.

All women who presented to this unit with a history of two or more spontaneous abortions and with more abortions than successful pregnancies were included in the study. The 50 women studied presented between July 1965 and March 1966 . During this period a total of 62 women presented with such a history, but 5 women either refused to take part in the study or took their discharge against medical advice. In the other 7 cases it seemed probable that the abortions were illegally induced or that the fathers were different.

The criteria for study were chosen as a compromise. Different workers have used various definitions of 'habitual abortion'. Many obstetricians agree with Eastman (1956) in reserving the term to cases in which the foetus is lost in three or more consecutive pregnancies. Stillbirths after the 28th week of pregnancy are usually included in such series.

Chromosomal and other genetic causes of abortion would not be expected to bring about consecutive abortion in every pregnancy, and series using Eastman's criteria should be biased against such abnormalities while tending to include an excess of maternal causes of abortion (e.g. uterine defects). Rowley et al. (1963) insisted on three abortions, but not necessarily consecutive. 
The present patients have a rate of foetal loss in excess of $50 \%$ as compared with a rate of abortion in normal populations of 11 to $15 \%$ (Stevenson and Warnock, 1959; Warburton and Fraser, 1964).

At the time of their inclusion in the study there was no firm evidence of other causes of abortion in any patient, though most of them had not been completely investigated to exclude such causes. All had negative serological tests for syphilis. None had $\mathrm{Rh}$ antibodies but two had specific group A haemolysins. Illegally induced abortion is, of course, well recognized in this unit, but its incidence is difficult to assess. There was no evidence of criminal interference in any of the pregnancies of these subjects. All denied such interference and 30 of the 50 women had shown a genuine desire to have children by spending a period of prophylactic rest in hospital during or before the course of the study.

Of the 50 women, 48 were pregnant at the time of their inclusion: 26 presented with a threatened or inevitable abortion and 22 were admitted for prophylactic rest owing to a bad previous history. One of the remaining two women was referred as an out-patient for consideration of cervical suture, having had 7 spontaneous abortions and no successful pregnancies, the other was admitted as a case of threatened abortion but was found to be suffering from menstrual irregularity only (she had a history of 6 pregnancies with 5 spontaneous abortions and one neonatal death at full term).

Chromosome preparations were made from lymphocytes of peripheral blood by a modification of the method of Moorhead et al. (1960). The woman and her husband were studied in every case. At least 50 metaphases were counted for each individual and at least 6 of the better metaphases were photographed to prepare karyotypes. In order to preserve the consecutive nature of the series, individuals were not excluded because of difficulty in obtaining suitable preparations from their lymphocytes. There were no absolute failures, but only poor preparations were obtained from a few individuals even after several cultures. The results in these cases must be less conclusive.

Chromosome preparations were made from the abortuses whenever possible using explant cultures of skin, connective tissue, or amnion by a modification of the method of Harnden and Brunton (1965) or phytohaemagglutinin stimulated lymphocytes from thymus and spleen by a modification of the method of Baker and Atkin (1963). The latter method produced good preparations after only 48 hours in culture but was rarely practicable for studying spontaneously aborted material which was usually macerated or autolysed. Amnion was the most useful tissue and gave results in cases where the foetus was so macerated that internal organs were hardly identifiable.

When possible, at least 50 metaphases were counted and 6 were photographed for karyotyping as in the adults.

No limit was put on the duration of pregnancy of the abortuses, though it has been established that chromosomal abnormalities are common only in those of the first trimester. It was considered that a different type of chromosomal abnormality might be found in the foetuses of women subject to abortion or that previous $\mathbb{D}$ abortions might modify the time at which abortion $\mathbb{D}$ occurs. Chromosomally abnormal foetuses do occa- sionally survive into the later stages of pregnancy, as $\frac{\vec{\sim}}{3}$ was the case with the triploid foetuses of 32 weeks of Edwards et al. (1967) and of 38 weeks (S. Walker, 1966, personal communication).

\section{Results}

In all of the 50 men and in 49 women the modal chromosome number was 46 . In the remaining $\vec{\omega}$ woman who has now had 5 pregnancies with 4 근 spontaneous abortions the modal chromosome number was 45 and the karyotype showed a t(DqDq) (Fig. 1). The translocation was familial and had $\overrightarrow{i r}$ apparently been transmitted to the patient by her 을 father. No other cases of abortion were admitted in the family but the only other known female carrier was unmarried. Infertility was a feature of some of the male carriers.

There was no convincing evidence of chromosome mosaicism in any of the adults in this series. Cells with non-modal chromosome counts showed random differences except in two women in each of whom three cells were found with 47 chromosomes and an apparently identical karyotype. In one, the extra chromosome appeared to be of the $\mathrm{C}$ group (no abnormalities of sex chromatin were found in the buccal smears), and in the other there was an extra $D$ chromosome. In the latter case an aborted foetus was successfully karyotyped and found to have 46 chromosomes, with an apparently normal female complement. Thus, even if there was true maternal mosaicism it appeared to have no relevance to this particular abortion.

In one woman there was a reciprocal translocation, $t(1$ ? $-; \mathrm{Gq}+)$ (Fig. 2). The anomaly was apparently similar to that described in one individual by Maganius et al. (1967). This patient was of low intelligence and had been deaf at least since very early childhood. She had had 6 pregnancies, with 4 spontaneous abortions and 2 normal children. The second child, a boy born during the course of the study, is a carrier of the translocation in balanced form (Fig. 3). Investigation of other members of the family was not permitted, but the mother and maternal half sister have long-standing deafness, and the patient was the only child of her mother's present marriage though no contraceptive measures had been used.

These were the only clear translocations in the series, but minor anomalies of the 'marker chromosome' type were found in 6 men and 2 women (Table I). 

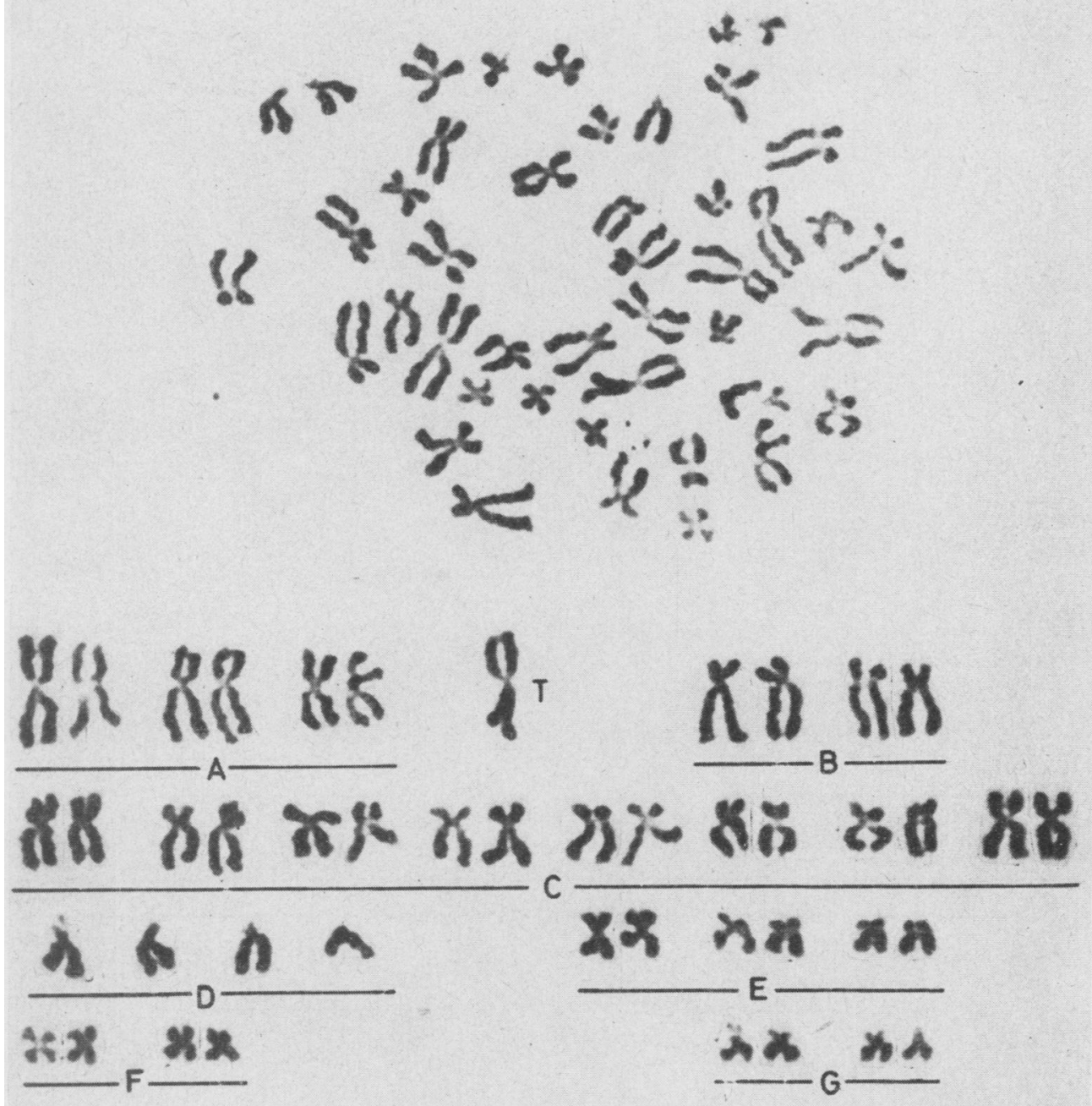

Fig. 1. Centric fusion $D / D$ translocation in a woman with a history of 4 spontaneous abortions and 1 normal pregnancy.

Family studies are being carried out where possible in these cases and may give further information on the possible correlation of such marker chromosomes with foetal loss.

The $\mathrm{Y}$ chromosome was assessed in all the males. Of the 50,12 had a $\mathrm{Y}$ chromosome obviously longer than the $G$ autosomes, but in only one case was the $\mathrm{Y}$ chromosome as long as chromosome 18 . There were no very short $\mathrm{Y}$ chromosomes and no structural rearrangements of the $\mathrm{Y}$ chromosome in this series. There appeared to be a steady variation in the length of the $\mathrm{Y}$ chromosome rather than a clear distinction between normal and long $Y$ chromosomes. It was concluded that no inference could be drawn from the presence of a long paternal $\mathrm{Y}$ chromosome in families subject to recurrent abortion.

The findings were compared with those recorded by Court Brown et al. (1966) in 438 randomly selected individuals from the Edinburgh area. The anomalies of the $\mathrm{Y}$ chromosome in both series were disregarded. The Edinburgh workers differentiate between structural rearrangements, such as translocations or inversions, and 'normal variants', such as unusual short arms on acrocentric chromosomes or variations in the long arms of chromosome 16. It was not considered that a distinction could be clearly made in all cases of this series, and the two 


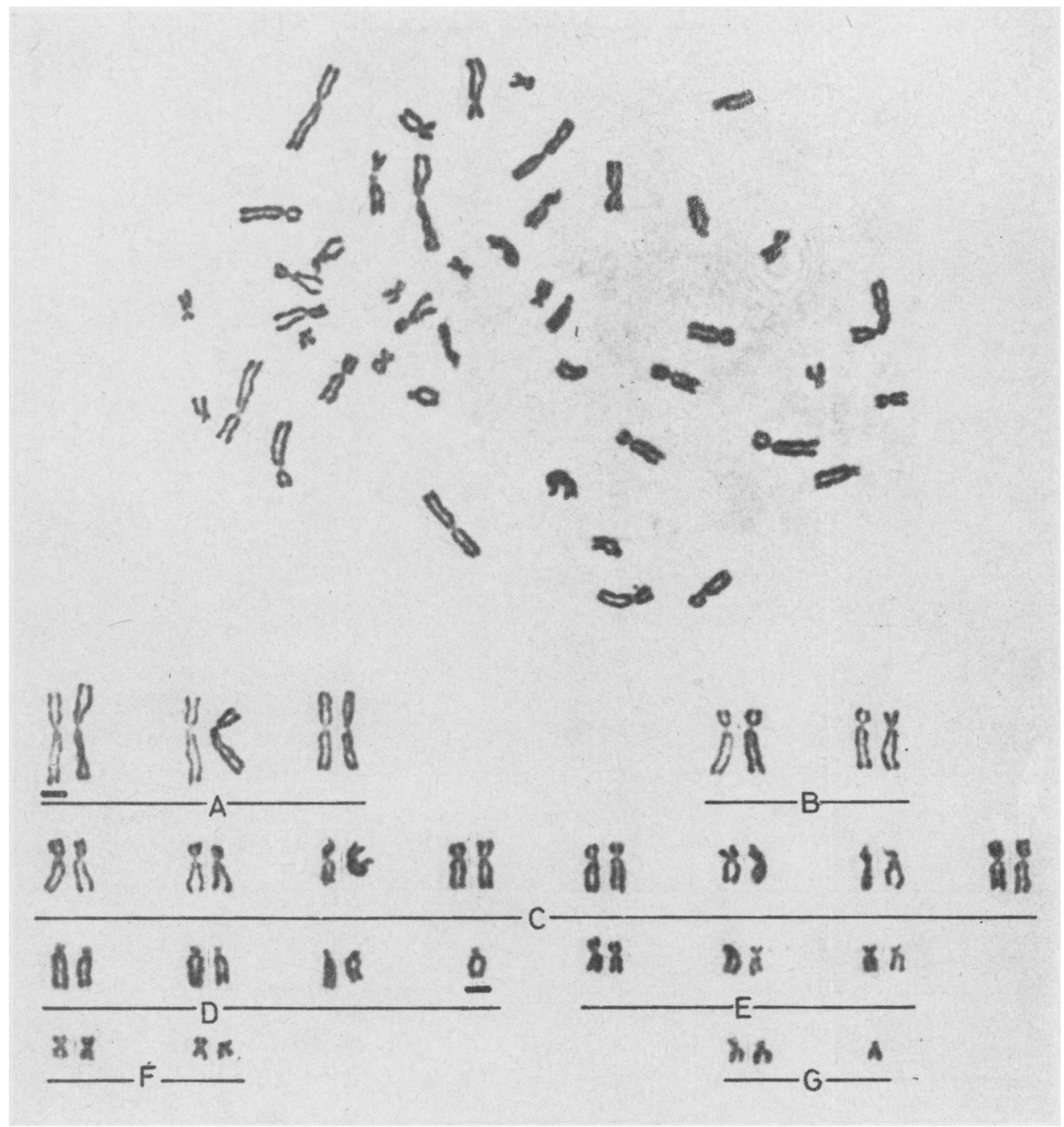

FIG. 2. $t(1 ?-; G q+)$ in a woman with a history of 4 spontaneous abortions and 2 normal pregnancies.

groups were therefore amalgamated. If only clear translocations are considered (two including one mosaic in 438 in the Edinburgh series) the difference is not significant $\left(\chi^{2}=0.932\right.$, for one degree of freedom, $0.5>p>0.3$ ). If all chromosomal variations, excluding those of the $\mathrm{Y}$ chromosome, are considered together (11 in 438 in Edinburgh, and 10 in 100 in this series) then $\chi^{2}=7.56$ and for one degree of freedom, $\mathrm{p}<0.01$. The significance of the findings should not be overemphasized, as apart from the difference in locality, the Edinburgh series has a high proportion of elderly individuals, and observer differences must be of great importance in scoring minor variations. It is, however, interesting that there was a chromosomal variation of some sort in 10 of the 50 pairs of adults subject to recurrent abortion in the Walton series.

During the course of the study at least one patient was found to have a non-chromosomal lesion which was certainly responsible for her recurrent abortions. A 39-year-old woman who had had 3 pregnancies all ending in spontaneous abortion after 12 years of involuntary infertility was found to have a unicornuate uterus at hysterectomy for persistent bleeding after a missed abortion. In no other patient was so clear a cause for the abortions detected. It was considered in 7 cases that there was sufficient evidence of cervical incompetence for a 


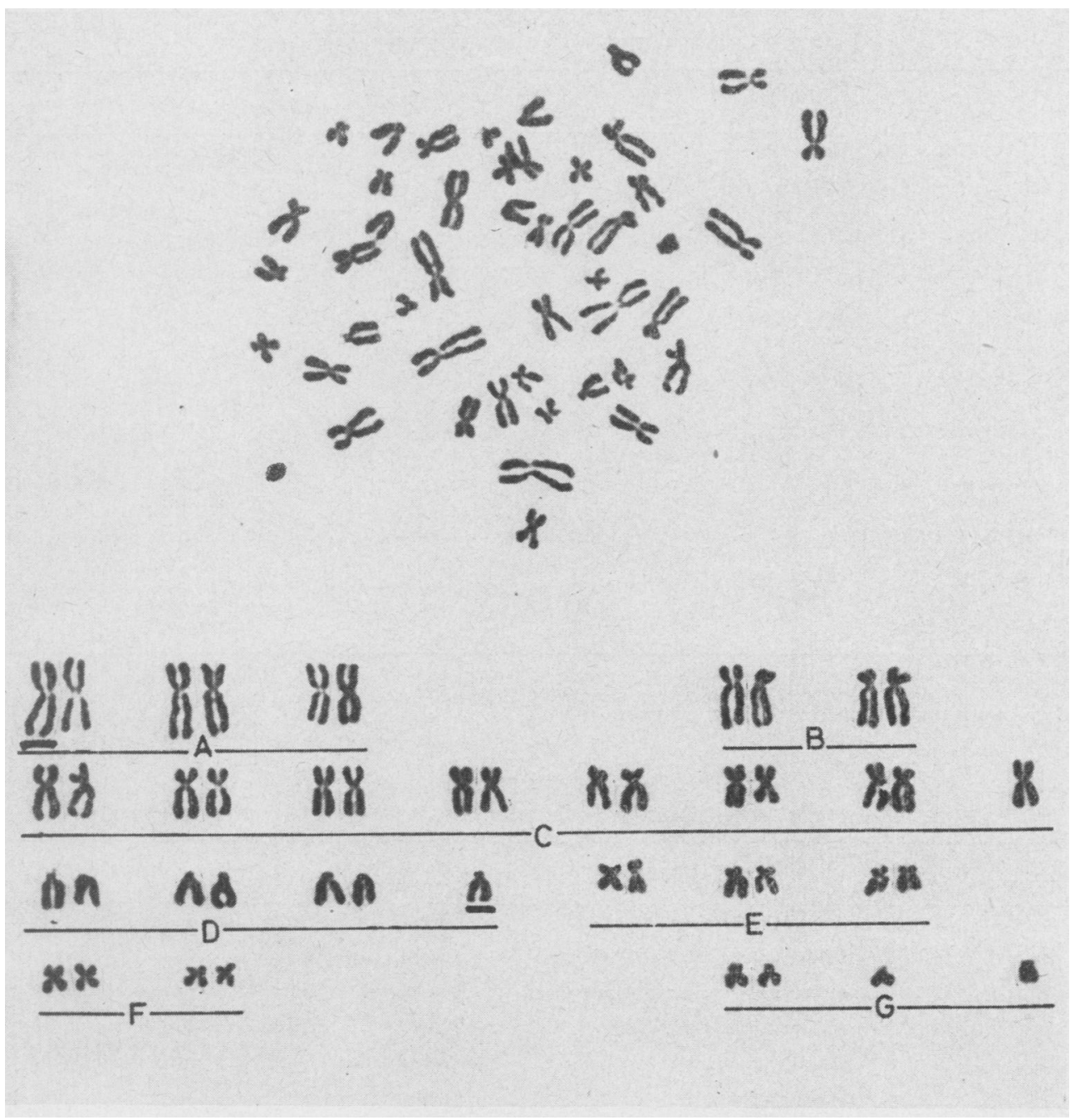

FIG. 3. $t(1 ?-; \mathrm{Gq}+)$ in an apparently normal male, child of the woman shown in Fig. 2.

Shirodkar suture to be inserted, but incompetence was probable in only 3 , and even in these cases it had not been proved by observation of foetal membranes bulging through the dilated cervix in the middle trimester of pregnancy. In one of these women foetal death occurred with a cervical suture in situ, and in another abortion became inevitable in spite of the suture.

One woman had established folic acid deficiency in a pregnancy which went to term. One had a parametrial cyst. 6 had toxaemia in other pregnancies, one of the husbands had defective semen, and 6 women had some psychological instability. In none of these cases could the defect be proved responsible for the abortions, and in some cases these conditions coexisted in the same woman (e.g. parametrial cyst, emotional lability, and Shirodkar suture in one case).

Foetuses. During the course of the study 28 women aborted and one produced a small, macerated, stillborn foetus at term. Foetal material was retrieved from 16 of the abortions, but in one case it was accidently placed in formalin. Chromosome preparations were made successfully from 8 of the remaining 15 specimens (Tables II and III). The rate of success was closely related to the state of preservation of the material, as has been found by other workers. The tissues were usually autolysed and the specimen was often broken. Only fragments of membranes were sometimes obtained, 
TABLE I

ADULTS IN WHOM VARIANT KARYOTYPES WERE FOUND

\begin{tabular}{|c|c|c|c|c|}
\hline $\begin{array}{c}\text { Pair } \\
\text { Number }\end{array}$ & $\begin{array}{l}\text { Affected } \\
\text { Subject }\end{array}$ & Karyotype & Pregnancy Sequence & Remarks \\
\hline $\begin{array}{l}1 \\
3\end{array}$ & $\begin{array}{l}\text { Husband } \\
24 \text { years } \\
\text { Wife } \\
25 \text { years }\end{array}$ & $\begin{array}{l}46, X Y, G s+ \\
46, X X, ? t(18 p-; G p+)\end{array}$ & $\begin{array}{l}\text { A26, A24, A9, SB31, UD28* } \\
\text { A12, A12* }\end{array}$ & $\begin{array}{l}\text { Shirodkar suture inserted before intrau- } \\
\text { terine death in last pregnancy }\end{array}$ \\
\hline $\begin{array}{l}5 \\
7\end{array}$ & $\begin{array}{l}\text { Wife } \\
25 \text { years } \\
\text { Wife } \\
28 \text { years }\end{array}$ & $\begin{array}{l}45, \mathrm{XX}, \mathrm{D}-, \mathrm{D}-, \mathrm{t}(\mathrm{DqDq})+ \\
46, \mathrm{XX}, \mathrm{t}(1 \mathrm{p}-; \mathrm{Gq}+)\end{array}$ & $\begin{array}{l}A 12, A 12, A 9, N 41^{\star}, A 12 \\
A 13, N 39, A 10, A 27, A 10, N 37^{\star}\end{array}$ & $\begin{array}{l}\text { Familial translocation; child not a carrier } \\
\text { Second child carrier of translocation in } \\
\text { balanced form }\end{array}$ \\
\hline 16 & $\begin{array}{l}\text { Husband } \\
23 \text { years }\end{array}$ & 46,XY,Ds + & $\mathrm{A} 10, \mathrm{~A} 9, \mathrm{~N} 40^{\star}$ & \\
\hline 18 & $\begin{array}{l}\text { Husband } \\
40 \text { years }\end{array}$ & $46, X Y, C ? q-, G p+$ & A20, A16, A12, N40, A11* & \\
\hline 25 & $\begin{array}{l}\text { Husband } \\
26 \text { years }\end{array}$ & $46, \mathrm{XY}, \mathrm{Gp}+$ & N40, A10, A9, A10, N40* & \\
\hline 38 & $\begin{array}{l}\text { Husband } \\
20 \text { years }\end{array}$ & $46, \mathrm{XY}, \mathrm{Gp}+$ & A12, A11* & $\begin{array}{l}\text { Male foetus karyotyped } 46, X Y \text {, normal } \\
\text { G autosomes }\end{array}$ \\
\hline 40 & $\begin{array}{l}\text { Husband } \\
21 \text { years }\end{array}$ & $46, X Y, G q-$ & N37, A10, A15, N39* & $\begin{array}{l}\text { Second child born after family was } \\
\text { studied }\end{array}$ \\
\hline 45 & $\begin{array}{l}\text { Wife } \\
22 \text { years }\end{array}$ & $46, \mathrm{XX}, \mathrm{Aq}+$ & $\mathrm{A} 25, \mathrm{~A} 6, \mathrm{~A} 22^{\star}$ & $\begin{array}{l}\text { Death in utero probably preceded abor- } \\
\text { tion by many weeks in first and last } \\
\text { pregnancies }\end{array}$ \\
\hline
\end{tabular}

Pregnancy symbols: A spontaneous abortion; N birth of apparently normal child; SB stillbirth; UD intrauterine death; * index pregnancy; figures indicate probable duration of pregnancy
Karyotype nomenclature is that of the Chicago Conference (1966).

TABLE II

FOETUSES FROM WHICH SUCCESSFUL TISSUE CULTURES COULD NOT BE MADE

\begin{tabular}{|c|c|c|c|c|}
\hline $\begin{array}{l}\text { Pair } \\
\text { Number }\end{array}$ & $\begin{array}{c}\text { Duration of } \\
\text { Pregnancy (wk.) }\end{array}$ & Details & Sex & Remarks \\
\hline 1 & 28 & Probably normal but macerated & Female & Dead in utero for at least 2 weeks; Shirodkar \\
\hline 4 & 14 & Grossly macerated & Probably male & Sanguineous vaginal discharge for 4 weeks \\
\hline 20 & 12 & Intact empty sac of membranes & Not known & Intermittent vaginal discharge for 3 weeks \\
\hline 24 & 24 & Apparently normal & Female & Abortion preceded by rupture of membranes; \\
\hline 27 & 17 & Grossly macerated & Probably male & $\begin{array}{l}\text { specimen accidentally placed in formalin } \\
\text { Much smaller than compatible with duration }\end{array}$ \\
\hline 28 & 11 & Grossly macerated & Not certain & $\begin{array}{l}\text { of pregnancy } \\
\text { Smaller than compatible with duration of }\end{array}$ \\
\hline $\begin{array}{l}30 \\
39\end{array}$ & $\begin{array}{l}16 \\
12\end{array}$ & $\begin{array}{l}\text { Only fragments of membranes recovered } \\
\text { Only fragment of membranes recovered }\end{array}$ & $\begin{array}{c}\text { Not known } \\
\text { Not known }\end{array}$ & \\
\hline
\end{tabular}

TABLE III

FOETUSES SUCCESSFULLY KARYOTYPED

\begin{tabular}{|c|c|c|c|}
\hline $\begin{array}{l}\text { Pair } \\
\text { Number }\end{array}$ & $\begin{array}{c}\text { Duration of } \\
\text { Pregnancy (wk.) }\end{array}$ & Details of Abortus & Karyotype \\
\hline $\begin{array}{r}8 \\
31 \\
33 \\
37\end{array}$ & $\begin{array}{l}20 \\
20 \\
11 \\
13\end{array}$ & $\begin{array}{l}\text { Apparently normal male } \\
\text { Apparently normal female } \\
22 \text { mm. foetus; sex not certain } \\
\text { Broken specimen; upper parts only } \\
\text { available }\end{array}$ & $\begin{array}{ll}\text { 46,XY } & \text { Normal male } \\
46, X X & \text { Normal female } \\
46, X X & \text { Normal female } \\
46, X Y & \text { Normal male }\end{array}$ \\
\hline 38 & 11 & Macroscopically normal male & $\begin{array}{l}\text { 46,XY Normal male } \\
\text { G autosomes normal; father has } \\
G p+\end{array}$ \\
\hline 42 & 24 & $\begin{array}{l}\text { Macerated male foetus much smal- } \\
\text { ler than compatible with duration } \\
\text { of pregnancy }\end{array}$ & $46, \mathrm{XY}^{\top}$ Normal male \\
\hline $\begin{array}{l}44 \\
50\end{array}$ & $\begin{array}{l}15 \\
11\end{array}$ & $\begin{array}{l}\text { Empty sac of membranes } \\
\text { Fragment of amnion only retrieved }\end{array}$ & $\begin{array}{l}\text { Normal male } \\
\text { Normal male }\end{array}$ \\
\hline
\end{tabular}


and even the foetal sex could then be determined only by karyotyping.

The 8 foetuses successfully studied all had 46 chromosomes and an apparently normal karyotype. One male foetus did not have a $\mathrm{Gp}+$ for which the father was heterozygous which was present in the father. There was no evidence of mosaicism in any foetus. The male foetuses in particular were examined carefully for the presence of cells with XX sex chromosome constitution. These were not found in any, though lymphocyte cultures in addition to cultures of skin and amnion were available in two of the male foetuses. Thus, none of the series showed evidence of foetal invasion by maternal lymphocytes in the manner suggested by Taylor and Polani (1965) in a case of recurrent abortion.

\section{Discussion}

The absence of aneuploid or polyploid foetuses from this series, though it is too small to be conclusive, suggests that there may be a difference in the incidence of such abnormalities in the offspring of women prone to abortion as compared with random abortions. Four of the embryos karyotyped were aborted during the first trimester and one of the others, though expelled early in the second trimester, consisted of an empty chorionic sac. In specimens of this type the incidence of chromosomal abnormalities has been reported as from 33\% (Kerr and Rashad, 1966) to $66 \%$ (Thiede and Salm, 1964).

It might be concluded that these cases of recurrent abortion were caused by maternal abnormalities, such as cervical incompetence or endocrine insufficiency, and that there was therefore no associated foetal abnormality.

The fact that no foetal parts were present in one of the specimens and that most of them showed evidence of death in utero long preceding the abortions, argue against this. The macroscopical findings were much the same in the 8 foetuses from which successful cultures could not be made (Table II).

These early foetal deaths would be compatible with a lethal embryonic genetic constitution due either to inherited lethal genes without chromosomal abnormality, or possibly to structural rather than numerical abnormalities of chromosomes. Some of the abnormalities would not necessarily be detectable by present techniques.

It was not practicable to undertake cultures of tissues other than lymphocytes in every adult, though it had been planned to do so for the parents of any aneuploid foetus which might be found. Even negative findings in cultures of blood and skin would not exclude the possibility of gonosomal mosaicism, but the absence of chromosome mosaicism from the lymphocyte cultures together with the finding of no aneuploid foetuses in the small series suggest that parental chromosome mosaicism is not a frequent cause of recurrent abortion.

Carriers of balanced translocations were considered likely to produce chromosomally unbalanced offspring which would probably be aborted as suggested by Bateman (1964). All karyotypes were examined with care to detect translocations whenever possible, but in the expectation that some significant translocations would not be detectable or be detectable only with difficulty in either balanced or unbalanced form by the methods now available.

It was considered highly probable that the two clear cases of translocation in this series $t(D q D q)$ and $t(1$ ? -;Gq +$)$ were responsible for the recurrent abortions in the respective families.

In the case of the minor abnormalities, some of which may be due to translocation, the situation is less clear. Such marker chromosomes are now usually considered to be harmless variants of the normal. The reported incidence of $3 \%$ of such anomalies in the general population (Court Brown et al., 1966) does not in itself imply that they are without pathological effect. The incidence of spontaneous abortion is about $15 \%$ of all pregnancies, and approximately $2 \%$ of the pregnancies concluded in this unit were found to be in women whose history fulfilled the criteria of this study. In addition to the isolated reports of minor chromosomal anomalies in families with recurrent abortions an increased incidence of such anomalies has been reported in families subject to congenital heart disease (German, Ehlers, and Engle, 1966) and in the families of children with Down's syndrome (Mikkelsen, 1967; Starkman and Shaw, 1967).

The findings of severe, specific malformations in cases of deletion of relatively small chromosomal fragments (cri-du-chat syndrome, deletions from the long or short arms of chromosome 18, and deletion of a $G$ autosome) suggest that deletions of relatively small fragments of chromatin may in some cases be lethal in utero. As is the case with trisomies and the 45,X condition it is probable that most embryos so affected are aborted. Many such cases must be overlooked. The criteria for clinical recognition of such syndromes should be (1) the presence of specific abnormalities which are compatible with survival to later pregnancy and (2) the deletion of chromatin from a site where its absence is apparent, such as a relatively small chromosome or from the short arms of a larger chromosome. Addition of similar quantities of chromatin would 
presumably be less lethal, but the genes involved would determine this.

Law and Masterson (1966) described two cases of the syndrome of deletion from the long arms of chromosome 18 occurring in a sibship where the mother was carrying a translocation from the long arms of a chromosome 18 to the short arms of a G autosome. Cases of this sort confirm that at least some acrocentric short arm anomalies are due to translocation, but it is only rarely that the confirmatory evidence of a clear reciprocal anomaly and specifically abnormal offspring will be found. In a similar family described by Nance et al. (1968) the other chromosome involved in the translocation could not be identified.

Histories of known translocation carriers rarely show abortion occurring in the expected ratio. There is often a difference in the fertility of carriers of the same sex in the same family. This aspect of the problem may not be understood until it is possible to detect and karyotype very early abnormal embryos of the kind described by Hertig et al. (1959), some of which would probably not have survived to the stage of implantation.

It may be that as some women lose $45, \mathrm{X}$ or trisomic foetuses by abortion while others maintain the pregnancies to term producing abnormal offspring, so there are other women in whom the abnormal embryos never become implanted and who therefore have no recognizable abortions.

Before minor chromosomal anomalies are dismissed as innocuous, the relative fertility and abortion proneness of the carrier and of his or her family should be assessed. It was found, however, that retrospective questioning about abortion, especially in previous generations, is unlikely to produce accurate results.

It is concluded that familial translocations are responsible for some cases of recurrent abortion. The varying results so far obtained by different workers are probably due to the different criteria used in selecting cases but also to the very small numbers which have been studied. Further studies are necessary to determine the general frequency of translocations in such families and to assess the degree of correlation between minor chromosomal anomalies and recurrent abortions on reduced fertility.

The inference that some aborted foetuses have structural rather than numerical chromosomal abnormalities implies the need for parental studies in the case of aborted foetuses found to have 46 chromosomes. In the $t(1 ; G)$ family here reported any foetus having a deficiency of the translocated portion of chromosome 1 could have been considered normal, particularly if only a few poor metaphases had been available for study, as is often the case with spontaneous abortions. The carrier of a balanced translocation may have a more obviously abnormal karyotype than an unbalanced individual, but studies of all members of the family will sometimes be necessary before it is certain.

All couples seeking medical advice because of frequent abortion (and those complaining of infertility) should be karyotyped. The aborted foetuses should be studied whenever possible. If a translocation is found, prophylactic treatment is unlikely to be helpful but the woman may be spared more drastic investigation and treatment. It was found in this study that parents accepted the situation well if they were told that the probability of having a normal pregnancy was 2 in 3 (as would be expected in a $t(D q D q)$ carrier assuming that effectively monosomic embryos do not survive long enough for pregnancy to be detected and that effectively trisomic embryos are aborted).

\section{Summary}

Chromosome studies were carried out on an almost consecutive series of 50 women who presented to a single unit with a history of two or more spontaneous abortions and of fewer full-term pregnancies than abortions. Only those who refused to co-operate or whose abortions were probably induced were excluded. The husbands of all the women were also studied, and an attempt was made to karyotype all aborted foetuses retrieved from these women. Eight foetuses were successfully karyotyped.

Two of the women were found to be carriers of balanced translocations. One of them had a $t(D q D q)$, the other had a $t(1$ ? $-; G q+)$. Eight of the other adults had minor autosomal variations. The total number of variations was significantly in excess of that found in 438 randomly chosen adults by Court Brown et al. (1966).

All the 8 foetuses had 46 chromosomes and an apparently normal karyotype. One male foetus did not have a $G$ autosome with unusually long short arms, which was present in the father.

No certain evidence of chromosome mosaicism was found in any adult or foetus.

The author is indebted to Mr. S. J. Barr, Mr. C. J. K. Hamilton, and Mr. J. K. P. Perera, of Walton Hospital, whose patients were studied and whose co-operation was invaluable; and to Professor C. A. Clarke who made the study possible. Dr. S. Walker and the staff of the Cytogenetics Department provided constant advice, encouragement, and technical help. 
This work formed part of a thesis for the degree of M.D. in the University of Liverpool and was carried out while the author was in receipt of a grant from the Nuffield Foundation.

\section{REFERENCES}

Baker, M. C., and Atkin, N. B. (1963). Short-term culture of lymphoid tissue for chromosome studies. Lancet, 1, 1164.

Bateman, A. J. (1964). Partial aneuploidy; a third mode of inheritance of human disease. ibid., 1,310 .

Bishun, N. P., Mannion, P. L., Rashad, M. N., Neely, M. R., Morton, W. R. M., and Burke, G. (1964). Chromosomal mosaicism in a case of repeated abortion. ibid., $1,936$.

Carr, D. H. (1963). Chromosomal abnormalities and their relation to disease. Canad. med. Ass. F., 88, 456.

- (1967). Chromosome anomalies as a cause of spontaneous abortion. Amer. F. Obstet. Gynec., 97, 283.

Chicago Conference (1966). Standardization in Human Cytogenetics. Birth Defects: Original Article Series II, 2. The National Foundation, March of Dimes, New York.

Court Brown, W. H., Buckton, K. E., Jacobs, P. A., Tough, I. M., Kuenssberg, R. V., and Knox, J. D. E. (1966). Chromosome Studies on Adults, Eugenics Laboratory Memoirs, XLII. Cambridge University Press, London.

Eastman, N. J. (1956). Williams' Obstetrics, 11th ed., p. 529. Appleton Century Crofts, New York.

Edwards, J. H., Yuncken, C., Rushton, D. I., Richards, S., and Mittwoch, M. (1967). Three cases of triploidy in man. Cytogenetics, 6, 81 .

German, J., Ehlers, K. H., and Eng!e, M. A. (1966). Familial congenital heart disease. II Chromosomal studies. Circulation, $34,517$.

Harnden, D. G., and Brunton, S. (1965). The skin culture technique. In Human Chromosome Methodology, p. 57. Ed. by J. J. Yunis. Academic Press, New York and London.

Hertig, A. T., Rock, J., Adams, E. C., and Menkin, M. C. (1959). Thirty-four fertilised human ova, good, bad and indifferent, recovered from 210 women of known fertility: a study of biologic waste in early human pregnancy. Pediatrics, 23, 202.

Inhorn, S. L., Therman, E., and Patau, K. (1964). Cytogenetic studies in spontaneous human abortion. Amer. F. clin. Path., 42, 528.

Jacobsen, P., Dupont, A., and Mikkelsen, M. (1963). Translocation in the 13-15 group as a cause of partial trisomy and spontaneous abortion in the same family. Lancet, $2,584$.

Jacobson, C. B., and Barter, R. H. (1967). Some cytogenetic aspects of habitual abortion. Amer. F. Obstet. Gynec., 97, 666.

Kelly, S., Almy, L., Jakovic, L., and Buckner, L. (1965). Autosomal monosomy in a spontaneous abortion. Lancet, 1, 166.

Kerr, M., and Rashad, M. N. (1966). Chromosome studies on spontaneous abortions. Amer. F. Obstet. Gynec., 94, 322.

Law, E. E., and Masterson, J. G. (1966). Partial deletion of chromosome 18. Lancet, 2,1137 .

Maganius, N. H., Archambault, L., Becker, K. L., and Winnacker, J. L. (1967). A $1 / G$ translocation in a member of a kindred with a marker chromosome. Arch. intern. Med., 119, 297.

Mikkelsen, M. (1967). Down's syndrome at young maternal age. Cytogenetical and genealogical study of eighty-one families. Ann. hum. Genet., 31, 51 .

Moorhead, P. S., Nowell, P. C., Mellman, W. J., Battips, D. M., and Hungerford, D. A. (1960). Chromosome preparations of leukocytes cultured from human peripheral blood. Exp. Cell Res., 20, 613.
Nance, W. E., Higdon, S. H., Chown, B., and Engel, E. (1968). Partial E-18 long-arm deletion. Lancet, 1, 303.

Rowley, P. T., Marshall, R., and Ellis, J. R. (1963). A genetical and cytological study of repeated spontaneous abortions. Ann. hum. Genet., 27, 87.

Schmid, W. (1962). A familial chromosome abnormality associated with repeated abortions. Cytogenetics, 1, 199.

Starkman, M. N., and Shaw, M. W. (1967). Atypical acrocentric chromosomes in negro and caucasian mongols. Amer. f. hum. Genet., 19, 162.

Stevenson, A. C., and Warnock, H. A. (1959). Observations on the results of pregnancies in women resident in Belfast. I Data relating to all pregnancies ending in 1957. Ann. hum. Genet., 23, 382.

Szulman, A. E. (1965). Chromosomal aberrations in spontaneous human abortions. New Engl. F. Med., 272, 811.

Taylor, A. I., and Polani, P. E. (1965). XX/XY mosaicism in man. Lancet, 1, 1226.

Thiede, H. A., and Salm, S. B. (1964). Chromosome studies of human spontaneous abortions. Amer. f. Obstet. Gynec., 90, 205.

Warburton, D., and Fraser, F. C. (1964). Spontaneous abortion risks in man: Data from reproductive histories collected in a medical genetics unit. Amer. F. hum. Genet., 16, 1.

Waxman, S. H., Arakaki, D. T., and Smith, J. B. (1967). Cytogenetics of fetal abortions. Pediatrics, 39, 425.

Wingate, L. (1965). Chromosome abnormality as a possible cause of habitual abortion. Bristol med.-chir. F., 80, 5.

\section{Addendum}

Since this paper was prepared there have been two relevant reports.

Bishun and Morton (1968) examined lymphocyte preparations from 27 women each of whom had lost the products of conception on two or more occasions. One of these patients had prominent satellites on a D chromosome, one had 45,X/46,XX mosaicism, and one had a high proportion of endoreduplicating cells in lymphocyte culture.

Pergament, Kadotani, and Sato (1968) examined 39 couples and 4 women who had experienced repeated abortions or stillbirths. One woman had a t(DqDq) and 5 subjects had minor chromosomal variations (2 women had asymmetrical No. 1 chromosome pairs, 2 men each had a satellited chromosome 17 or 18, and 1 woman had a deletion of the short arms of a G autosome).

\section{REFERENCES}

Bishun, N. P., and Morton, W. R. (1968). Chromosome studies on women who have had two or more unsuccessful pregnancies. $\mathcal{F}$. Obstet. Gynaec. Brit. Cwith, 75, 66.

Pergament, E., Kadotani, T., and Sato, H. (1968). Chromosome studies in repeated spontaneous abortions and stillbirths. Amer. f. Obstet. Gynec., 100, 912. 